\title{
Direct Sunlight Influences Postharvest Temperature Responses and Ripening of Five Avocado Cultivars
}

\author{
Allan B. Woolf \\ The Horticulture and Food Research Institute of New Zealand Ltd. Mt. Albert Research Centre, Private Bag \\ 92169, Auckland, New Zealand \\ Asya Wexler, Dov Prusky, Elana Kobiler, and Susan Lurie \\ Department of Postharvest Science, ARO, The Volcani Center, POB 6, Bet Dagan 50250, Israel
}

\begin{abstract}
AdDITIONAL INDEX wORDs. fruit ripening, heat-shock proteins, Persea americana, postharvest physiology, chilling injury, heat treatment, pathology

Abstract. Effect of direct sunlight on the postharvest behavior of five avocado (Persea americana Mill.) cultivars (Ettinger, Fuerte, Hass, Horshim and Pinkerton) was examined. Probes placed 6 to $7 \mathrm{~mm}$ under the peel showed that the temperature an the side exposed to the sun could be as much as 15 to $20^{\circ} \mathrm{C}$ higher than the temperature of shade fruit, while the nonexposed side of the fruit was $\approx 5^{\circ} \mathrm{C}$ higher than the shade fruit. With the exception of 'Ettinger', sun fruit, and especially the exposed side, were found to be most tolerant to postharvest 50 and $55^{\circ} \mathrm{C}$ hot water treatments. Similarly, storage of fruit at $0{ }^{\circ} \mathrm{C}$ for between 3 to 6 weeks caused severe chilling injury to shade fruit, with less effect on sun fruit. Furthermore, there was little or no damage on the exposed side of the sun fruit. During postharvest ripening at $20{ }^{\circ} \mathrm{C}$, sun fruit showed a delay of between 2 to 5 days in their ethylene peak compared with shade fruit. The exposed side of the sun fruit was generally firmer than the nonexposed side, and the average firmness was higher than that of shade fruit. Activities of polygalacturonase and cellulase were similar in shade and sun fruit of similar firmness. After inoculation with Colletotrichum gloeosporioides (Penz.) Penz@sacc., the appearance of lesions on sun fruit occurred 2 to 3 days after shade fruit. Levels of heat-shock proteins were examined using western blotting with antibodies for Class I and II cytoplasmic heat-shock proteins. Class I reacted with proteins from the exposed side of sun fruit and Class II with proteins from both sides of sun fruit. Thus, it is clear that preharvest exposure of fruit to the sun can result in a wide range of postharvest responses.
\end{abstract}

Exposure of fruit to direct sunlight can result in temperatures in excess of $15^{\circ} \mathrm{C}$ above the ambient air temperature (Ferguson et al., 1998). Flesh temperatures between 40 and $50^{\circ} \mathrm{C}$ have been recorded in a range of growing environments. These temperatures may be responsible for the variability observed in postharvest responses (Woolf et al., 1999). Such temperatures are similar to postharvest treatments which have been shown to increase fruit tolerance to high (Chan and Linse, 1989; Paull and Chen, 1990) and low temperatures (Lurie and Klein, 1991; Wild and Hood, 1989; Woolf et al., 1997), increase shelf life and slow fruit ripening (Lurie and Klein, 1992), maintain fruit firmness during storage (Klein and Lurie, 1990), and induce heat-shock protein (HSP) gene expression and protein synthesis (Lurie and Klein, 1991; Paull, 1990; Sabehat et al., 1996).

Exposure of New Zealand-grown 'Hass' avocado (Persea americana) fruit to the sun can result in fruit temperatures as high as $43{ }^{\circ} \mathrm{C}$ (Woolf et al., 1999). The fruit so exposed (sun fruit) have higher tolerance to postharvest heat $\left(50^{\circ} \mathrm{C}\right.$ hot water $)$ and cold $(0$ ${ }^{\circ} \mathrm{C}$ storage) treatments than shade fruit (Woolf et al., 1999). In addition, the shelf life of nonstored sun fruit is longer (Woolf et al., 1999), and fruit firmness differs between the exposed and shaded sides of the sun fruit (Woolf and Ferguson, unpublished data). Thus, it appears that the preharvest temperatures experienced by avocado fruit affects their postharvest behavior in a manner similar to postharvest heat treatments (HTs), where $38^{\circ} \mathrm{C}$ treatments can increase tolerance to high (Woolf and Lay-Yee,

Received for publication 4 Jan. 1999. Accepted for publication 5 Jan. 2000. We wish to thank the German-Israeli Research Authority (GIARA), and the Binational United States-Israel Research and Development Foundation (BARD) for partially funding this work. This work was also supported in part by the New Zealand Foundation for Research, Science and Technology CO6429, and the New Zealand Avocado Industry Council. The cost of publishing this paper was defrayed in part by the payment of page charges. Under postal regulations, this paper therefore must be hereby marked advertisement solely to indicate this fact.
1997) or low temperatures (Sanxter et al., 1994; Woolf et al., 1995, Woolf, 1997), and can increase shelf life (Woolf et al., 1995).

Growing conditions in Israel are significantly different to those of New Zealand with ambient air temperatures during summer of $>35{ }^{\circ} \mathrm{C}$ (temperatures which have been shown to induce HSPs under New Zealand conditions). These significant differences and the wide range of commercial avocado cultivars grown in Israel lead us to study the effect of exposure to sunlight of five avocado cultivars in response to high and low temperature as carried out previously in New Zealand. In addition we investigated respiration, ripening characteristics and cell wall softening enzymes, and the effect of field heat on the diurnal cycles of HSPs and resistance to a fungal pathogen.

\section{Materials and Methods}

Fruit TYPES AND Source. Two avocado fruit types were employed in the following experiments. Shade fruit were fruit selected from under the leaf canopy, and sun fruit picked from the south side of the tree which was in direct sunlight at noon. For the sun fruit, the side facing the sun was marked for future reference and this is referred to as the exposed side, while the opposite side is the nonexposed side of sun fruit.

Harvests were conducted in the fall and early winter (November to January). At each harvest, firmness and dry weight (DW) were determined. The dates of harvest are shown in Table 1.

For each of the 5 avocado cultivars (Ettinger, Fuerte, Pinkerton, Horshim and Hass), the following series of experiments were conducted using fruit from commercial orchards located in the Jordan Valley and the coastal plain near Tel Aviv, Israel. Fruit temperature was monitored for each cultivar prior to harvest during October to January (late fall to midwinter). Fruit temperatures were monitored on at least one shaded fruit, and on the 
Table 1. Duration of hot water treatments (HWTs; min) applied to fruit of five avocado cultivars harvested from either of two regions at commercial maturity. The HWTs designated with a $\boldsymbol{V}$ were applied first to one harvest of shade fruit. From the results obtained, one 50 and/or a $55^{\circ} \mathrm{C} \mathrm{HWT}$ were selected and applied to a second harvest of sun and shaded fruit 1 week later $(\boldsymbol{*})$.

\begin{tabular}{|c|c|c|c|c|c|c|c|c|c|c|c|c|c|c|c|c|c|}
\hline \multirow[b]{3}{*}{ Cultivar } & \multirow{3}{*}{$\begin{array}{l}\text { Harvest } \\
\text { date }\end{array}$} & \multirow[b]{3}{*}{ Control } & \multicolumn{15}{|c|}{ HWT (min) } \\
\hline & & & \multicolumn{8}{|c|}{$50{ }^{\circ} \mathrm{C}$} & \multicolumn{7}{|c|}{$55^{\circ} \mathrm{C}$} \\
\hline & & & 1 & 3 & 5 & 7.5 & 10 & 15 & 20 & 25 & 1 & 2 & 3 & 5 & 7.5 & 10 & 15 \\
\hline Ettinger & 27 Oct. 1997 & $V$ & $--^{z}$ & --- & --- & --- & $\checkmark$ & $V$ & $V$ & $V$ & --- & --- & --- & $V$ & $\checkmark$ & $\boldsymbol{x}$ & $\checkmark$ \\
\hline Fuerte & 12 Nov. 1997 & $\checkmark$ & $\checkmark$ & $\checkmark$ & $\checkmark$ & $\boldsymbol{x}$ & $\checkmark$ & --- & --- & --- & $\checkmark$ & $\boldsymbol{x}$ & $\checkmark$ & $\checkmark$ & $\checkmark$ & --- & --- \\
\hline Pinkerton & 23 Nov. 1997 & $\checkmark$ & $\checkmark$ & $\checkmark$ & $\checkmark$ & $\checkmark$ & $\checkmark$ & $\checkmark$ & $\checkmark$ & --- & 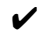 & --- & $\checkmark$ & $\checkmark$ & $\boldsymbol{x}$ & --- & --- \\
\hline Horshim & 3 Dec. 1997 & $\boldsymbol{V}$ & --- & --- & $\checkmark$ & 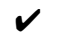 & $\checkmark$ & $\checkmark$ & $\checkmark$ & --- & $\checkmark$ & --- & $\checkmark$ & $\boldsymbol{x}$ & $\checkmark$ & $\checkmark$ & --- \\
\hline Hass & 4 Jan. 1998 & $\checkmark$ & $\checkmark$ & $\checkmark$ & $\checkmark$ & $\boldsymbol{x}$ & 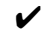 & --- & --- & --- & $\checkmark$ & $\checkmark$ & $\checkmark$ & $\checkmark$ & $\checkmark$ & --- & --- \\
\hline
\end{tabular}

${ }^{\mathrm{z} H o t}$ water treatment not examined.

exposed and nonexposed sides of sun fruit. Air temperature was not monitored as this has been found to be nearly identical to that of shaded fruit (Woolf et al., 1999). At harvest, a sample of 10 fruit was placed in plastic bags and maturity determined by dry matter analysis for each fruit. About $10 \mathrm{~g}$ of tissue was dried for $36 \mathrm{~h}$ at $65^{\circ} \mathrm{C}$ and reweighed. Fruit firmness was measured through the skin using a Digital Force Gauge (Chatillon, Lyons, France) (conical point $6 \mathrm{~mm}$ diameter $\times 4 \mathrm{~mm}$, measuring peak force at a speed of $20 \mathrm{~mm} \cdot \mathrm{min}^{-1}$ ).

EXPERIMENTS. For each cultivar, two harvests were made as follows: 1) shade fruit were picked, 50 and $55^{\circ} \mathrm{C}$ hot water treatments (HWTs) applied and the fruit response determined during the following week at $20{ }^{\circ} \mathrm{C}$ (see Table 1 for HWT durations applied, and harvest details). On the basis of the response of shade fruit to HWTs, one duration of either 50 or 55 ${ }^{\circ} \mathrm{C}$ HWTs was applied to fruit of the second harvest; 2) sun and shade fruit were harvested and three postharvest responses were examined: tolerance to high temperatures $\left(50\right.$ and/or $\left.55^{\circ} \mathrm{C}\right)$, low temperature $\left(0^{\circ} \mathrm{C}\right)$, and ripening rate at $20^{\circ} \mathrm{C}$. Sun and shade fruit were stored at $0{ }^{\circ} \mathrm{C}$ for between 3 and 6 weeks, depending on cultivar, to induce chilling injury. For ripening measurements, fruit were held at $20{ }^{\circ} \mathrm{C}$, ethylene production and respiration monitored (see below), and after the ethylene peak was reached, firmness of shade fruit, sun fruit, and the difference between exposed and nonexposed sides of the fruit determined. For each cultivar, fruit were size-picked.

Fruit TeMPERATURE MEASUREMENTS. Temperature was measured using Hobo temperature dataloggers (Onset Computer Corp., Pocasset, Mass.). The bead-like thermistor probe ( $2 \mathrm{~mm}$ diameter; resolution $0.4{ }^{\circ} \mathrm{C}$ ) was inserted on a diagonal into the flesh for a length of $\approx 14 \mathrm{~mm}, 6$ to $7 \mathrm{~mm}$ into the flesh. The $3-\mathrm{mm}$ diameter hole was filled with Plastilena (a nontoxic synthetic clay; Plastilena Ltd., Tel Aviv, Israel) and temperature logged every $15 \mathrm{~min}$.

Hot WATER TREATMENTS. HWTs were carried out at either 50 ${ }^{\circ} \mathrm{C}$ or $55^{\circ} \mathrm{C}$ for various durations on the day of harvest or $1 \mathrm{~d}$ after (held at $20^{\circ} \mathrm{C}$; relative humidity of $80 \%$ ) using a $60 \mathrm{~L}$ tank with recirculating pump $\left(\approx 1.5 \mathrm{~L} \cdot \mathrm{s}^{-1}\right)$. Depending on cultivar, four to seven HWT durations were performed at both 50 and $55^{\circ} \mathrm{C}$ with 10 fruit/treatment, while control fruit were not treated (Table 1). Water temperature was monitored and was accurate to $\pm 0.3^{\circ} \mathrm{C}$. Following treatment, fruit were removed and allowed to dry on mesh racks. Within $25 \mathrm{~min}$, fruit were placed in commercial avocado trays $\left(2.5 \mathrm{~kg}\right.$ cardboard boxes) at $20^{\circ} \mathrm{C}$. Peel damage was evaluated daily (see below) and the maximum value (achieved after 5 to $7 \mathrm{~d}$ ) is presented.

Cold storage. On the day of harvest, fruit were placed into storage at $0 \pm 0.5{ }^{\circ} \mathrm{C}$ (relative humidity of $95 \%$ ). Fruit samples were removed after 3, 4 or 6 weeks depending on the cultivar. Ten exposed, and 10 shaded fruit were used for each storage treatment. External damage was rated upon removal from storage and $3 \mathrm{~d}$ later, and the maximum value is presented.

External damage (due to both heat damage and chilling injury) was rated on a relative scale of 0 to 3 as described by Woolf and Lay-Yee (1997), where $0=$ no occurrence, $0.5=<10 \%, 1.0=10 \%$ to $20 \%, 1.5=21 \%$ to $50 \%, 2=51 \%$ to $75 \%, 2.5=76 \%$ to $90 \%$, $3.0=>90 \%$ of the fruit surface.

ELECTROLYTE LEAKAGE. In addition to measurement of external damage, electrolyte leakage of skin tissue from the exposed and nonexposed sides of sun fruit, and from shade fruit was determined. The method was as described by Woolf (1997) using a TH27 conductometer (El-Hama Instrument Co., Tel Aviv, Israel). The only difference was that total leakage was measured after freeze-thawed discs were blended in an Ultra-turrax (Jancke and Kundel, Munich, Germany), and the solution filtered through two layers of cheesecloth.

RIPENING RATE. Ten each of sun and shade fruit were held at 20 ${ }^{\circ} \mathrm{C}$ and their ethylene production and respiration rate $\left(\mathrm{CO}_{2}\right.$ production) monitored. Individual fruit were placed in $2-\mathrm{L}$ jars which were closed for $1 \mathrm{~h}$ daily. Samples of the headspace were removed from a septum in the top of the jar by syringe and injected into a gas chromatograph for ethylene and $\mathrm{CO}_{2}$ determination. Ethylene was measured on a gas chromatograph equipped with an alumina column and flame ionization detector, and $\mathrm{CO}_{2}$ measured using a Poropak Q column (Supelco, London, U.K.) and a thermal conductivity detector (Philips PU4500; Pye Unicam, Cambridge. U.K.). After the fruit reached their ethylene peak, fruit firmness was measured on the east/west sides of the sun fruit and was compared with two measurements on the shade fruit. Firmness of the exposed and nonexposed sides (south and north sides) or the sun fruit was also measured and the difference between the two determined for each fruit. Measurements were made through the skin using a Digital Force Gauge (described previously).

Cell wall degrading enzyMes. After ethylene and $\mathrm{CO}_{2}$ had been monitored and firmness measured for 'Fuerte', a 15-g flesh sample was taken from the exposed and nonexposed side of the sun fruit, and $15 \mathrm{~g}$ from the shade fruit and frozen at $-20^{\circ} \mathrm{C}$. Each sample was ground in $50 \mathrm{~mL}$ of $1 \mathrm{~mol} \cdot \mathrm{L}^{-1} \mathrm{NaCl}$ and $0.05 \mathrm{~mol} \cdot \mathrm{L}^{-1} \mathrm{Na}$ acetate buffer, pH 5.0. The extract was filtered through cheesecloth and used as a crude enzyme extract for measuring activity of both polygalacturonase and cellulase by viscometry. Five milliliters of extract was incubated at $30{ }^{\circ} \mathrm{C}$ with $10 \mathrm{~mL}$ of $1 \%$ carboxymethylcellulose in $0.1 \mathrm{~mol} \cdot \mathrm{L}^{-1} \mathrm{Na}$ acetate buffer, $\mathrm{pH} 5.5$ for cellulase or with $10 \mathrm{~mL}$ of $1 \%$ citrus pectin in $0.1 \mathrm{~mol} \cdot \mathrm{L}^{-1} \mathrm{Na}$ acetate buffer $\mathrm{pH} 5.0$ for polygalacturonase activity. Viscosity was measured at the beginning of incubation and after $30 \mathrm{~min}$ 


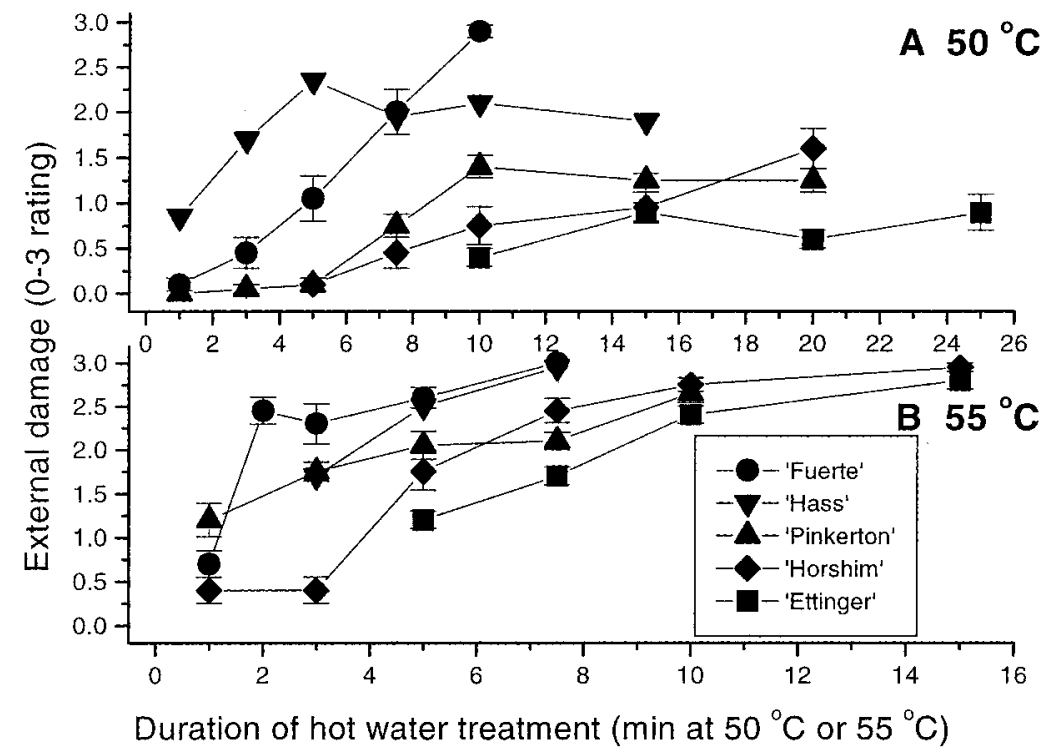

using a viscometer. Boiled extracts examined in the same manner served as a control.

WESTERn ANALYSIS. Two sun and shade fruit from 'Hass' and 'Fuerte' were harvested at 1200, 2000, and $0800 \mathrm{HR}$ for HSP analysis in December and January. Over this period, the temperature of shade, and exposed and nonexposed sides of representative fruit were monitored. At the time of sampling, the exposed side of the fruit was marked and after transport to the laboratory, tissue was sampled (<30 min after harvest). One $12 \mathrm{~mm}$ diameter disk without peel weighing $\approx 0.5 \mathrm{~g}$ from each fruit was taken for western analysis. Equal loadings of $20 \mathrm{mg}$ protein/lane separated on $12 \%$ SDS-PAGE gels. They were then electroblotted onto nitrocellulose filters and exposed to two different antibodies; Class I HSP (18.1 ku in Pisum sativum L.) and Class II HSP (17.6 ku in pea) prepared against recombinant pea proteins (gift of $\mathrm{L}$. Nover). Visualization was by using a second antibody conjugated to alkaline phosphatase.

Colletotrichum PATHOGENICITY RESISTANCE. 'Fuerte' fruit (both shade and sun, 15 fruit each) were inoculated on the day of harvest by placing a $10 \mu \mathrm{L}$ suspension containing $10^{6}$ spores $/ \mathrm{mL}$ of Colletotrichum gloeosporioides on the peel at three locations in up to $25 \mathrm{~min}$. External damage was rated on a scale of 0 (no damage) to (complete damage). Data presented are the maximum levels developed (5 to 7 d at $20{ }^{\circ} \mathrm{C}$ ). Vertical bars represent SE. Legend in (B) applies to both figures.

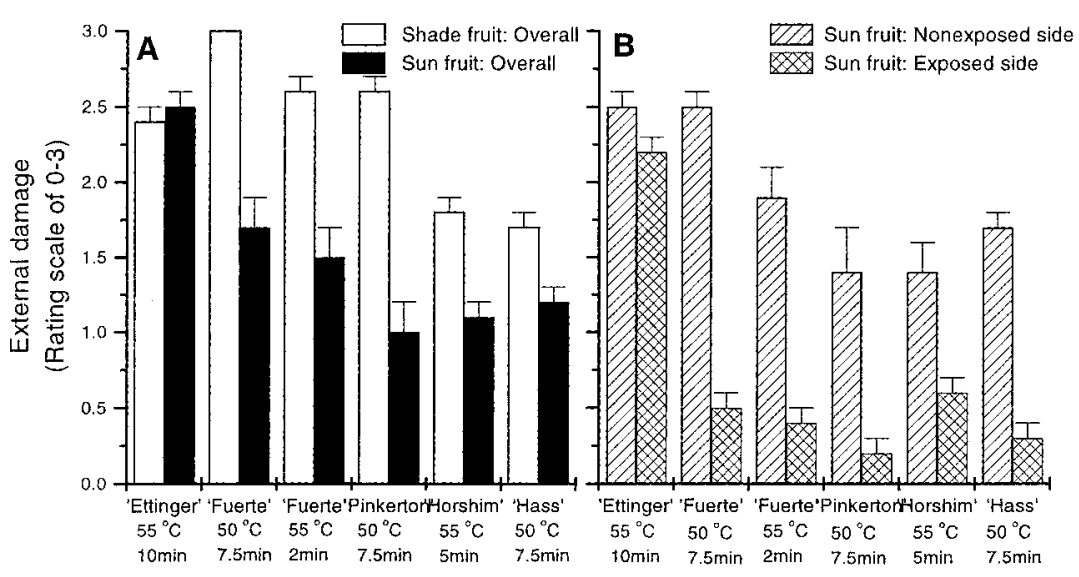

Fig. 2. External damage of hot water treated sun and shade fruit. (A) overall damage of sun and shade fruit and $(\mathbf{B})$ damage to exposed and nonexposed sides of sun fruit. External damage was rated on a scale of 0 (no damage) to 3 (complete damage). Data presented are the maximum levels developed (5 to 7 d at $20^{\circ} \mathrm{C}$ ). Vertical bars represent SE.

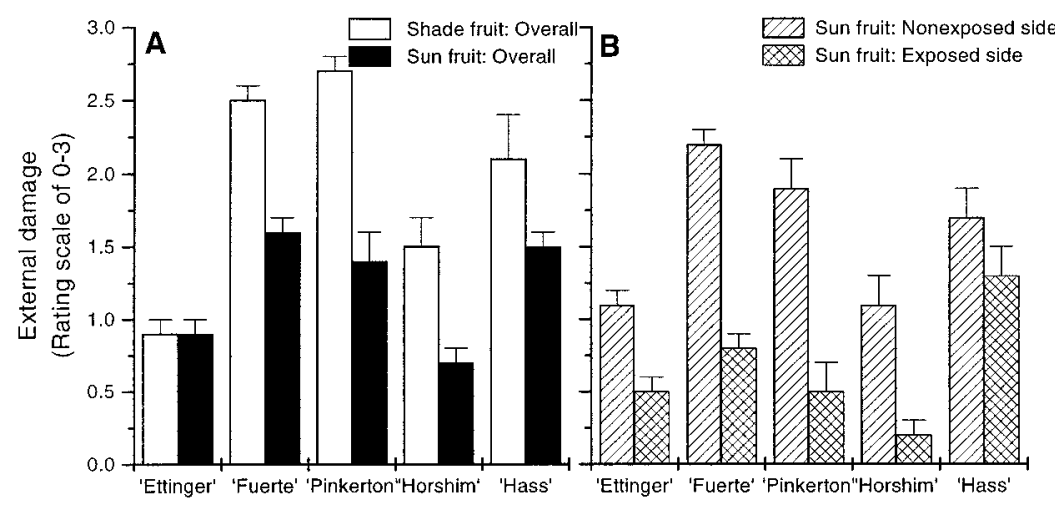

Fig. 3. External damage of sun and shade fruit following storage at $0{ }^{\circ} \mathrm{C}$ for 3 to 6 weeks. (A) overall damage of sun and shade fruit and (B) damage to exposed and nonexposed sides of sun fruit. External damage was rated on a sale of 0 (no damage) to 3 (complete damage). Data presented are the maximum levels developed ( $3 \mathrm{~d}$ at $\left.20^{\circ} \mathrm{C}\right)$. Vertical bars represent SE.
HARVEST ATTRIBUTES. Maturity at harvest for the five cultivars was $21.3 \%, 19.1 \%, 20.0 \%, 26.9 \%$ and $26.6 \%$ dry matter for Ettinger, Fuerte, Pinkerton, Horshim and Hass respectively. Fruit firmness at harvest fell into two ranges; 110 to $112 \mathrm{~N}$ for 'Ettinger' and 'Fuerte', and $124 \mathrm{~N}$ for the other cultivars.

Fruit temperature. The highest shade fruit temperature in November was $28.7^{\circ} \mathrm{C}$ (average maximum/minimum $25.2 / 13.0{ }^{\circ} \mathrm{C}$, respectively), and in December the maximum was $25.8^{\circ} \mathrm{C}$ (average maximum/minimum $22.5 / 10.3{ }^{\circ} \mathrm{C}$, respectively). On a sunny day, the exposed side of the sun fruit normally reached temperatures $>35{ }^{\circ} \mathrm{C}$ at $\approx 1000 \mathrm{HR}$, and remained above this temperature until $1500 \mathrm{HR}$ or later (data not presented). The maximum fruit temperature reached was 40 to $45^{\circ} \mathrm{C}$ during November, and 35 to $40{ }^{\circ} \mathrm{C}$ in December. The nonexposed side of the sun fruit reached $\approx 30^{\circ} \mathrm{C}$, and remained at these tempera-

each of two longitudinal rows (Prusky et al., 1991). ance and size of the lesions were measured daily. In addition, peel and flesh of 10 noninoculated determination of the presence of an antifungal carried out as described by Prusky et al. (1996). analyzed and presented using Origin (Microcal; Unless stated otherwise, only statistically significant results $(P<0.05)$ are discussed (as determined by ANOVA or F test).

\section{Results} tures for 3 to $4 \mathrm{~h}$. Although there were differences in the shade fruit temperatures between the two growing areas where fruit were sampled, weather factors such as cloud cover, rain, or wind 


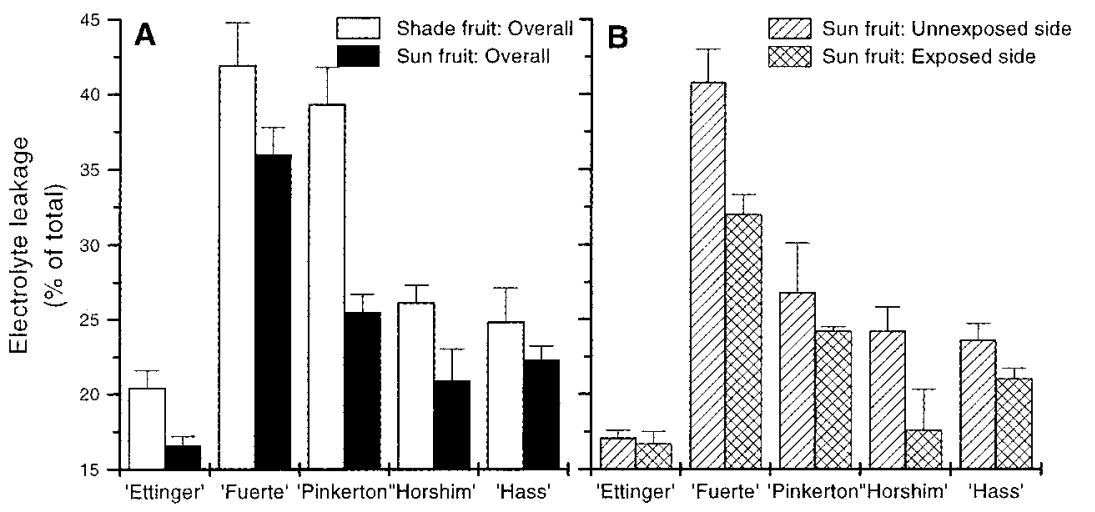

Chilling tolerance. Except for the earliest cultivar harvested, Ettinger, all cultivars showed greater chilling damage on shade fruit than on sun fruit (Fig. 3A). As was found for hot water damage, the exposed side suffered less chilling injury than the nonexposed side (Fig. 3B). However, even the nonexposed side of the sun fruit generally showed less damage than the shade fruit. 'Hass' and 'Ettinger' required longer times at $0{ }^{\circ} \mathrm{C}$ to induce peel damage than the other three cultivars.

Another measure of chilling injury is a change in the selective permeability of tissues. This was measured as electrolyte leakage from peel discs. The same pattern was found as for peel chilling

Fig. 4. Leakage of electrolytes from peel discs of avocado fruit after storage at 0 ${ }^{\circ} \mathrm{C}$ for 3 to 6 weeks. (A) leakage of sun and shade fruit and (B) leakage of exposed and nonexposed sides of sun fruit. Leakage was measured immediately after storage and is expressed as the percentage of total electrolytes. Vertical bars represent SE.

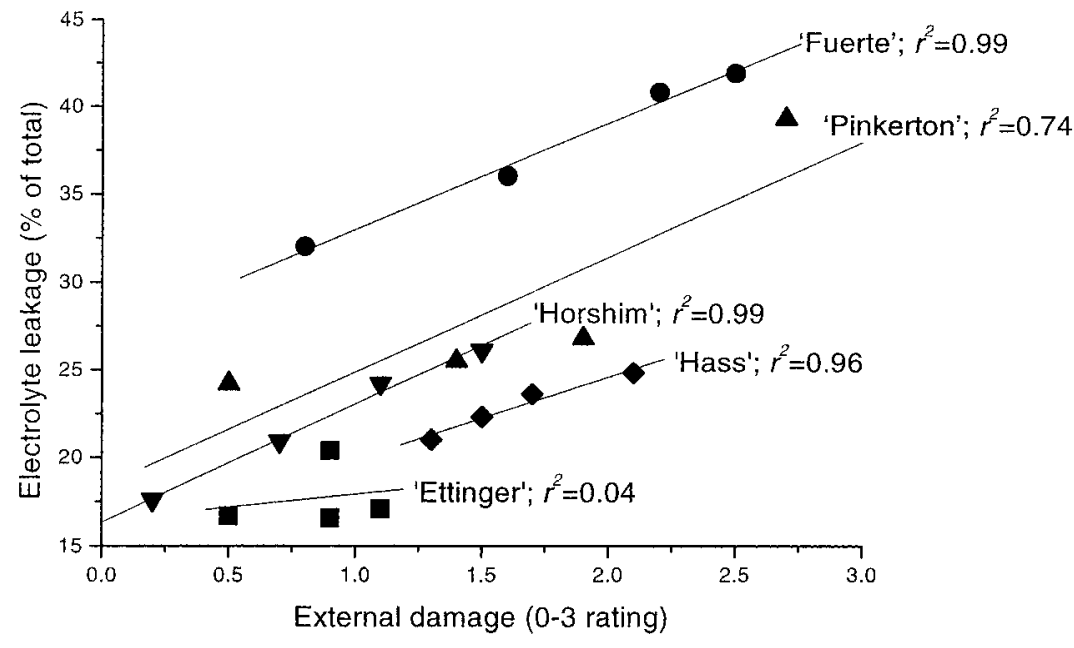

damage, with the shade fruit having the highest leakage (Fig. 4A), and the exposed side of the sun fruit the least leakage (Fig. 4B). In addition, the leakage from cultivars that showed the most damage, Fuerte and Pinkerton, was higher than those which showed less damage. The lowest leakage was from 'Ettinger' which also showed the least chilling injury. The correlation between external damage and electrolyte leakage was significant in all cultivars except Ettinger (Fig. 5).

Fruit Ripening. For all cultivars except Ettinger, firmness of the sun fruit was higher than shade fruit at the same time of measurement after harvest (Table 2). There was also a difference in firmness between the exposed and nonexposed side (exposed-nonexposed side) of the sun fruit, with the exposed side being firmer for all cultivars except Ettinger and Pinkerton. The differences in firmness between sun and shade fruit tended to decrease as the season progressed from fall to winter, with nearly $8 \mathrm{~N}$ difference between the two fruit types for 'Fuerte', but only $0.8 \mathrm{~N}$ for 'Hass'.

Polygalacturonase activity increased steadily as the fruit softened while cellulase reached a high level of activity when the fruit were relatively firm, and activity decreased only once the fruit softened below $3 \mathrm{~N}$ (data not presented). The increase in polygalacturonase activity occurred irrespective of whether they were sun or shade fruit, but took longer in sun fruit that softened more slowly. At the end of shelf life, the activities of both enzymes were similar in both types of fruit (data not presented).

The slower ripening of sun fruit seen in softening is also demonstrated in the rates of ethylene production of sun and shade fruit. The ethylene peak of sun fruit occurred 2 to $4 \mathrm{~d}$ after shade fruit in 'Fuerte', but only slightly later for 'Hass' (Fig. 6),

Table 2. Flesh firmness (N) of sun and shade fruit, and the average difference between exposed and nonexposed sides of sun fruit (exposed-nonexposed). Firmness was determined after all fruit had passed their peak ethylene production at $20{ }^{\circ} \mathrm{C}$. Mean values are presented \pm SE $(n=10)$.

\begin{tabular}{lccc}
\hline & \multirow{2}{*}{$\begin{array}{c}\text { Shade fruit } \\
\text { Cultivar }\end{array}$} & \multicolumn{2}{c}{ Sun fruit } \\
\cline { 3 - 4 } (overall) & Overall & Exposed-nonexposed \\
\hline Ettinger & $10.6 \pm 8.1$ & $8.5 \pm 5.9$ & -1.1 \\
Fuerte & $4.6 \pm 1.0$ & $12.3 \pm 3.4$ & 6.6 \\
Pinkerton & $5.6 \pm 0.9$ & $7.4 \pm 1.2$ & 0.0 \\
Horshim & $3.5 \pm 0.5$ & $5.0 \pm 0.9$ & 2.5 \\
Hass & $4.3 \pm 0.3$ & $5.1 \pm 0.2$ & 0.9 \\
\hline
\end{tabular}




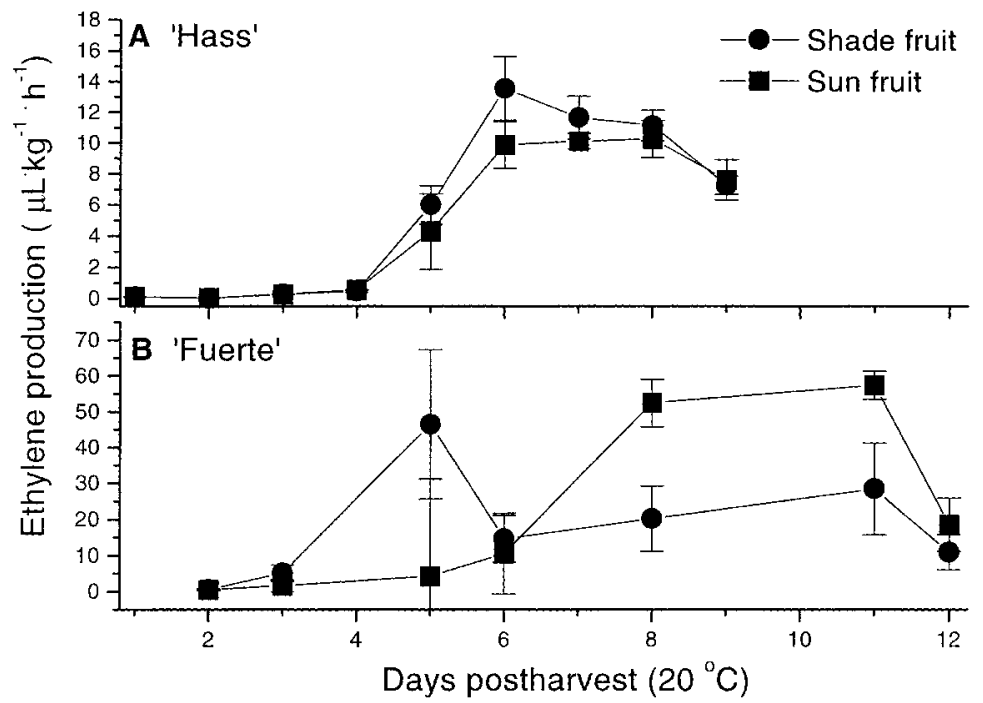

Fig. 6. Average ethylene production for sun and shade fruit of (A) 'Hass' and (B) 'Fuerte' avocado during ripening at $20^{\circ} \mathrm{C}$. Vertical bars represent SE. Legend in A applies to both figures.

\section{Fruit type \\ Exposure \\ Time (HR) \\ 0800 \\ $12002000 \quad 0800$ \\ A \\ Class II
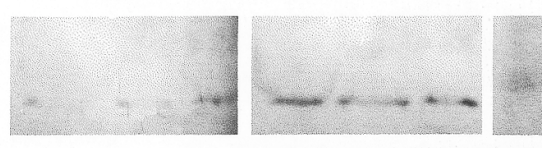 \\ B \\ Class I

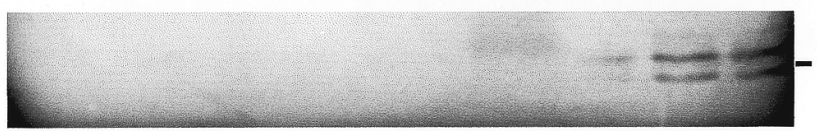 \\ Fig. 7. Western blot of protein extracted from flesh immediately below the skin of shade fruit, and the exposed and nonexposed sides of sun fruit. Fruit were sampled at 0800, 1200, and $2000 \mathrm{HR}$. (A) Class II low-molecular-weight heat- shock proteins and (B) Class I low-molecular-weight heat-shock proteins. $21 \mathrm{ku}$ is the molecular-weight marker lane.}

080012002000

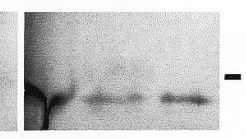

$-21 \mathrm{ku}$
$-21 \mathrm{ku}$ sun fruit had higher diene levels at all times. In the peel, diene levels of sun and shade fruit were not different for the first $7 \mathrm{~d}$, but subsequently the sun fruit showed a rise in diene peel levels such that sun fruit had twice the level of shade fruit (data not presented).

\section{Discussion}

Results obtained in Israel and in New Zealand (Woolf et al., 1999) demonstrate that high preharvest temperatures due to exposure to the sun dramatically affect a range of postharvest responses in several avocado cultivars. This suggests a universality of response between sun and shade fruit for the majority of commercial cultivars, in particular Hass and Fuerte, which are the two most important commercial cultivars. In this study, fruit exposed to the sun were more tolerant to temperature extremes (both high and low), and had a longer postharvest shelf life than shade fruit. The reasons for these beneficial responses of sun fruit may center around the fact that these fruit experience a diurnal temperature stress. The accumulation of heat shock proteins in the exposed fruit was an indication of their response to the stress. However, the fruit appeared to be conditioned to the stress since they develop normally on the tree, and ripen normally once harvested.

Responses of the sun fruit to HWTs and chilling temperatures were similar to the effects of postharvest high temperature treatments. For example, a postharvest water pretreatment of $1 \mathrm{~h}$ at $38^{\circ} \mathrm{C}$ reduces damage caused by either a $50^{\circ} \mathrm{C} \mathrm{HWT}$ (Woolf and Lay-Yee, 1997), or chilling-inducing storage temperatures of $0.5^{\circ} \mathrm{C}$ (Woolf, 1997). Similarly, postharvest hot air treatments of 38 to $40^{\circ} \mathrm{C}$ reduce chilling injury of 'Hass' (Florissen et al., 1996; Woolf et al., 1995), and 'Sharwil' (Sanxter et al., 1994) avoca-

although ethylene peak productions were similar in both types of fruit. The respiratory climacteric was not different in timing between sun and shade fruit (data not presented).

HeAT-SHOCK PROTEIns. Cross-reactivity of proteins extracted from the flesh of 'Hass' was found between Class I and II lowmolecular-weight HSPs. Class II cross-reacted with one protein on both sun and shade fruit (Fig. 7). Antigenic signal with Class I antibodies could be detected with two proteins only on the exposed side of sun fruit (Fig. 7).

Pathogen Resistance and diene Concentration. The resistance to decay of sun and shade fruit was determined by inoculation with $C$. gloeosporioides. Lesion development was initiated after $10 \mathrm{~d}$ at $20{ }^{\circ} \mathrm{C}$ (Fig. 8A). The shaded fruit exhibited more extensive and faster lesion development than the sun exposed fruit.

The initial concentration of the antifungal diene in the fruit flesh $1 \mathrm{~d}$ after harvest was similar in both sun and shade fruit (Fig. $8 \mathrm{~B})$. However, the diene content decreased to a greater extent in the shade fruit than the sun fruit during shelf life at $20^{\circ} \mathrm{C}$ such that dos. These responses to postharvest HWTs closely parallel the responses observed herein for sun fruit which repeatedly experienced similar temperatures $\left(>35^{\circ} \mathrm{C}\right)$ while on the tree. The correlation of electrolyte leakage and external chilling injury at the time of removal from storage for all cultivars (except 'Ettinger') has been observed previously for 'Hass' following postharvest conditioning treatments (Woolf, 1997).

The reason for the observed cultivar differences may be the date fruit were harvested. 'Ettinger' is harvested in October when air temperatures at midday can be $>30^{\circ} \mathrm{C}$, and the shade fruit as well as the sun fruit experience heat stress. Shade fruit reached 34 ${ }^{\circ} \mathrm{C}$ at midday while the sun fruit experienced above $40{ }^{\circ} \mathrm{C}$. Fruit from this cultivar reacted anomalously compared with the other four cultivars examined. They were very insensitive to HWTs and equally resistant to chilling injury. For example, it took 6 weeks at $0{ }^{\circ} \mathrm{C}$ for chilling injury to develop on 'Ettinger' compared with 3 weeks for 'Fuerte', and the chilling injury was found equally on sun and shade fruit.

The effect of sun exposure on fruit softening observed by the authors with four cultivars is consistent with the delayed ripening observed in 'Hass' grown in New Zealand (Woolf et al., 1999). Ripening of 'Hass' can be slowed by postharvest HTs applied by either water (Woolf, 1997) or air (Woolf et al., 1995), although some researchers have observed faster ripening (Florissen et al., 


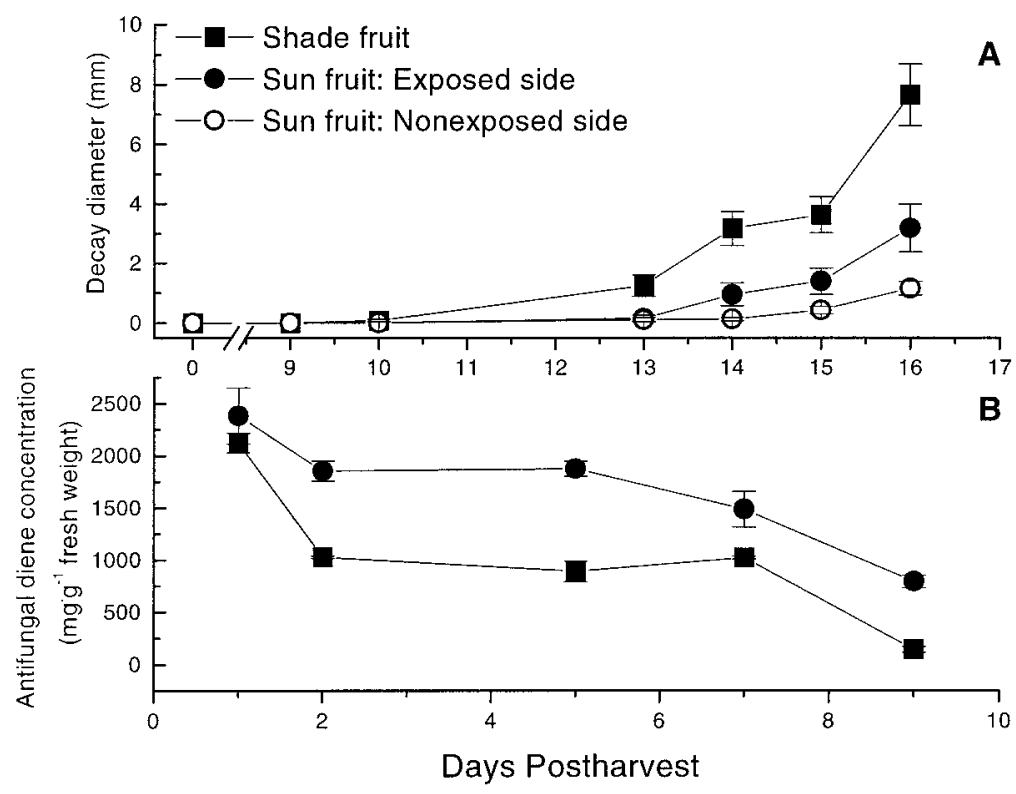

wavelengths. We feel that the UV response, if present, is a minor one for three reasons. The first reason is response of the early cultivar Ettinger to the different treatments. If exposure to UV light was the key effect, then it might be expected that this cultivar would also exhibit similar responses to the other cultivars, which it did not. Secondly, the antifungal diene is present in similar concentrations in both sun and shade fruit at harvest. The diene normally increases in concentration in response to UV light (Prusky and Keen, 1993), and therefore if UV radiation played a large role, higher levels of diene would be expected in sun fruit. Finally, Nedunchezhian et al. (1992) showed that although UV$B$ radiation results in some additional increase in HSP synthesis over the heat effect at 30 or $40^{\circ} \mathrm{C}$, at 10 or 20 ${ }^{\circ} \mathrm{C}$, there is little induction of low molecular weight HSPs by UV radiation. Therefore, temperature conditioning is likely to induce the major portion of the postharvest responses of the sun fruit, rather than exposure to UV.

In conclusion, preharvest exposure to the sun of

Fig. 8. Disease development and diene levels of 'Fuerte' fruit after harvest for sun and shade fruit. (A) diameter of lesions on the skin inoculated with spores of Colletotrichum gloeosporioides. (B) level of antifungal dienes in flesh tissue. Legend in (A) applies to both figures.

1996). Extended HTs ( 2 or $3 \mathrm{~d}$ at $38^{\circ} \mathrm{C}$ ) slows ripening of tomato fruit (Lycopersicon esculentum Mill.) (Lurie and Klein, 1992; Mitcham and McDonald, 1992). Avocados exposed to sun in the field experience repeated periods of temperatures of $35^{\circ} \mathrm{C}$ or higher for 4 to $5 \mathrm{~h}$ each day. Thus, the temperatures experienced in the field may influence the rate or ripening/softening in a manner similar to that of postharvest HTs. The relative softening rates of the different tissues examined (sun exposed, sun nonexposed, and shade fruit) also followed an inverse pattern to the peak temperatures experienced preharvest.

High temperatures generally depress normal protein synthesis and activate HSP synthesis (Ferguson et al., 1994; Lurie and Klein, 1991). Therefore, ripening processes dependent on continuous protein synthesis will be inhibited (Lurie et al., 1996). How long this effect will be maintained once the stress is removed may depend on how long the stress has been inflicted. Fruit can lose their ability to ripen if held at a high temperature for extended periods of time (Kagan-Zur et al., 1995; Komiyama et al., 1979). Thus, repeated exposure to the sun, and hence high flesh temperatures observed herein, may explain in part the slower ripening of sun compared with shade fruit.

Aside from changes to the ripening and thermotolerance responses, this work has also shown differences in the resistance of fruit types, and exposed locations on fruit to a fungal pathogen. Changes in the levels of antifungal dienes during ripening correlated with the relative sensitivity of the tissues to fungal attack since the exposed side of sun fruit had higher levels of diene than the shade fruit. It should be noted that the differences in resistance are not an anomaly due to the rate of ripening/softening of the three different tissues since, in four of the five cultivars, the exposed side of sun fruit softened more slowly than the nonexposed side (Table 2), yet it was less resistant to disease invasion (Fig. $8 \mathrm{~A}$ ). It is not clear why the nonexposed side of sun fruit was more resistant than the exposed sides and the shaded fruit.

Since temperature stress is caused by direct sunlight, it could be thought that part of the stress is a response to ultra violet (UV) wavelengths rather than to the heat response due to infrared avocado fruit has a profound effect on postharvest behavior. The effects noted herein may explain some of the variation found in avocado fruit after harvest in terms of tolerance to high and low temperatures, ripening rate, and resistance to disease infection. Since similar effects have been found in both Israel and New Zealand on a range of cultivars, the effect of exposure on postharvest responses is likely to be universal for many cultivars.

\section{Literature Cited}

Chan, H.T. and E. Linse. 1989. Conditioning cucumbers for quarantine heat treatments. HortScience 24:985-989.

Ferguson, I.B., S. Lurie, and J. Bowen. 1994. Protein synthesis and breakdown during heat shock of cultured pear (Pyrus communis L.) cells. Plant Physiol. 104:1429-1437.

Ferguson I.B., W. Snelgar, M. Lay-Yee, C.B. Watkins, and J.H. Bowen. 1998. Heat shock response in apple fruit in the field. Austal. J. Plant Physiol. 25:155-163.

Florissen, P., J.S. Ekman, C. Blumenthal, W.B. McGlasson, J. Conroy, and P. Holford. 1996. The effects of short heat-treatments on the induction of chilling injury in avocado fruit (Persea americana Mill). Postharvest Biol. Technol. 8:129-141.

Kagan-Zur, V., D.M. Tieman, S.T. Marlow, and A.K. Handa. 1995. Differential regulation of polygalacturonase and pectin methylesterase gene expression during and after heat stress in ripening tomato (Lycopersicum esculentum Mill.) fruits. Plant Mol. Biol. 29:1101-1110.

Klein, J.D. and S. Lurie. 1990. Prestorage heat treatment as a means of improving poststorage quality of apples. J. Amer. Soc. Hort. Sci. 115:255-259.

Komiyama, Y., M. Harakawa, and M. Tsuji. 1979. Influences of high temperature storage on the quality of plums. Jpn. Soc. Hort. Sci. 26:371-274.

Lurie, S., A. Handros, E. Fallik, and R. Shapira. 1996. Reversible inhibition of tomato fruit gene expression at high temperature. Plant Physiol. 110:1207-1214.

Lurie, S. and J.D. Klein. 1991. Acquisition of low temperature tolerance in tomatoes by exposure to high temperature stress. J. Amer. Soc. Hort. Sci. 116:1007-1012.

Lurie, S. and J.D. Klein. 1992. Ripening characteristics of tomatoes stored at $12{ }^{\circ} \mathrm{C}$ and $2{ }^{\circ} \mathrm{C}$ following a prestorage heat treatment. Scientia Hort. 51:55-64.

Mitcham, E.J. and R.E. McDonald. 1992. Effect of high temperature on cell wall modifications associated with tomato fruit ripening. Postharvest Biol. Technol. 1:257-264.

Nedunchezhian, N., K. Annamalainathan, and G. Kulandaivelu. 1992. 
Induction of heat shock-like proteins in Vigna sinensis seedlings growing under ultraviolet-B $(280-320 \mathrm{~nm})$ enhanced radiation. Physiol. Plant. 85:503-506.

Paull, R.E. 1990. Postharvest heat treatments and fruit ripening. Postharvest News Info. 1:355-363.

Paull, R.E. and N.J. Chen. 1990. Heat shock response in field grown ripening papaya fruit. J. Amer. Soc. Hort. Sci. 115:623-631.

Prusky, D. and W.T. Keen. 1993. Inducible preformed compounds and their involvement in the resistance of plant pathogens, p. 139-152. In: R. Reuveni (ed.). Novel approaches to integrated pest management. Lewis Publ. Inc., Chelsa, Mich.

Prusky, D., I. Kobiler, Y. Fishman, J.J. Sims, S.L. Midland, and N.T. Keen. 1991. Identification of an antifungal compound in unripe avocado fruit and its possible involvement in the quiescent infections of Colletotrichum gloeosporioides. J. Phytopath. 132:319-327.

Prusky, D., C. Wattad, and I. Kobiler. 1996. Effect of ethylene on activation of lesion development from quiescent infections of Colletotrichum gloeosporioides in avocado fruits. Mol. Plant Microbe Interactions 9:864-868.

Sabehat, A., D. Weiss, and S. Lurie. 1996. The correlation between heatshock protein accumulation and persistence and chilling tolerance in tomato fruit. Plant Physiol. 110:531-537.
Sanxter, S.S., K.A. Nishijima, and H.T. Chan, Jr. 1994. Heat-treating 'Sharwil' avocado for cold tolerance in quarantine cold treatments. HortScience 29:1166-1168.

Wild, B.L. and C.W. Hood. 1989. Hot dip treatments reduce chilling injury in long-term storage of 'Valencia' oranges. HortScience 24:109110.

Woolf, A.B. 1997. Reduction of chilling injury in stored 'Hass' avocado fruit by $38{ }^{\circ} \mathrm{C}$ water treatments. HortScience 32:1247-1251.

Woolf, A.B., S. Ball, K.J. Spooner, M. Lay-Yee, I.B. Ferguson, C.B. Watkins, A. Gunson, and S.K. Forbes. 1997. Reduction of chilling injury in the sweet persimmon 'Fuyu' during storage by dry air heat treatments. Postharvest Biol. Technol. 11:155-164.

Woolf, A.B., J.H. Bowen, and I.B. Ferguson. 1999. Preharvest exposure to the sun influences postharvest responses of 'Hass' avocado fruit. Postharvest Biol. Technol. 15:143-153.

Woolf, A.B. and M. Lay-Yee. 1997. Pretreatments at $38^{\circ} \mathrm{C}$ of 'Hass' avocado confer thermotolerance to $50{ }^{\circ} \mathrm{C}$ hot water treatments. HortScience 32:705-708.

Woolf, A.B. C.B. Watkins, J.H. Bowen, M. Lay-Yee, J.H. Maindonald, and I.B. Ferguson. 1995. Reduction of external chilling injury in stored 'Hass' avocado fruit by dry heat treatments. J. Amer. Soc. Hort. Sci. 120:1050-1056. 